\title{
Long-term monitoring of cropland transformation in Kolkata Metropolitan Area, India using open-source geospatial technologies
}

\author{
Shrabana Mazumder ${ }^{1,2} \cdot$ Joydeep Saha ${ }^{3} \cdot$ Gouranga Nandi $^{2} \cdot$ Mrinmoyee Naskar $^{2,4} \cdot$ Jibananda Gayen $^{2,5}$. \\ Debajit Datta² ${ }^{2}$
}

Received: 20 June 2020 / Accepted: 22 December 2020 / Published online: 11 January 2021

(c) The Author(s) $2021 \quad$ OPEN

\begin{abstract}
Urban and peri-urban agricultural practices are degrading throughout the developing world owing to unprecedented urban sprawling and consequent expansion of built-up areas. This study attempted to assess the changing land use/land cover patterns of Kolkata Metropolitan Area, India from 1990 to 2020 with special emphasis on the transformation trajectories of its urban and peri-urban agriculture as a case study using free and open-source software and multi-temporal geospatial database. It also aimed to project the transformation scenario of croplands in 2030 through application of the artificial neural network algorithm of the freely available Modules for Land Use Change Evaluation plugin. Results revealed a persistent spread of built-up areas by engulfing croplands, wetlands, vegetation and water bodies throughout the assessment period. An overall loss of $181.11 \mathrm{sq}$. km of croplands between 1990 and 2020 was estimated and found to be more prominent in the northern, eastern, and south-eastern parts of the study area. If the existing socio-economic framework and administrative mechanism would prevail as usual, then the projected land use patterns of 2030 would predict a further decrease of $15.46 \mathrm{sq} . \mathrm{km}$ in cropland area thereby culminating to a total $37.39 \%$ of it original extent since 1990. A theoretical three-stage model of land use conversion was developed from the empirical results as well as field observations and validated with the findings of the projected scenario. It indicated two primary conversion patterns for the study area, viz. (1) natural area to cropland to fallow land and then to built-up, and (2) natural area to fallow land to built-up. Few necessary management measures were suggested to mitigate this persistent loss of croplands and other natural areas.
\end{abstract}

Keywords Built-up expansion · Land use modelling · Suburbanization · Urban and peri-urban agriculture $\cdot$ Urban sprawl

\section{Introduction}

An exaggerated pace of urbanization is leading to incessant conversion of croplands into built-up and other nonfarm urban land uses worldwide at present, particularly along the city fringes [1-3]. This leads to noticeable environmental degradation in urban and peri-urban zones [4]. Waning of croplands creates intense pressure on food production, thereby escalating food prices. Overwhelming evidences had been found on the role of urban and periurban agriculture (UPA) as viable agroecosystems functioning towards the ecological, economic, and sociocultural sustenance of the citizens for many of the global metropolises [5-8]. The trend is more prominent in several cities of India where the continuous onslaught of the real estate and manufacturing sectors coupled with lacklustre implementation of the legal protective measures had resulted into disappearing greeneries including croplands

$\triangle$ Debajit Datta, debajit.geo@gmail.com | 'Department of Geography, Barasat Government College, Barasat 700124, India. ${ }^{2}$ Department of Geography, Jadavpur University, Kolkata 700032, India. ${ }^{3}$ Department of Geography, Bijoy Krishna Girls' College, Howrah 711101 , India. ${ }^{4}$ Department of Geography, Baruipur College, Baruipur 743610, India. ${ }^{5}$ Department of Geography, Sree Chaitanya College, Habra 743268, India. 
[9]. These transformations are culminating into grave ecological crisis and devastating the livelihoods of smallholder and marginal farmer communities hitherto thriving in the urban fringes $[4,10]$. Continuous monitoring and mapping of the UPA changes, therefore, become imperative towards formulation of any sustainable management plan and environmental conservation initiative for these cities [11]. Accordingly, the city of Kolkata, the third largest metropolitan area of India, had been analysed in the present research as a case study of long-term areal dynamics with respect to UPA transformations.

Extensive urbanization in Kolkata Metropolitan Area (KMA) has led to the fragmentation of UPA and created economic and environmental problems [11, 12]. Recent remote sensing-based studies had exhibited the spatiotemporal changes of land use/land cover (LULC) patterns in Kolkata and its surroundings [9, 12]. However, a conspicuous dearth of relevant studies focussing primarily on the landscape transformation in general and consequent changes in the UPA in particular had also been noticed [5]. In addition, site-specific studies emphasizing on the transformation of UPA were found to be rare for KMA. Hence, the present study attempted to assess the changing LULC patterns of KMA with special emphasis on UPA transformation over the last 30 years and subsequently aimed at predicting the possible future UPA transformation scenario in the metropolitan area in 2030 exclusively using free and open-source software (FOSS) and geospatial database. The selection of free and open-source data and technologies were deliberately done to facilitate the active involvement of environmental enthusiasts, ordinary citizens, and concerned farmers in mapping, analysing, and disseminating the outcomes of the research to its most possible extent [13-15]. As per the authors' conviction, this would certainly advance the access of geospatial information to the commons and, in turn, lead to enhanced levels of environmental activism towards conserving the remaining greeneries in the city fringes.

\section{Methodology}

\subsection{Delineation of the study area}

The urban agglomeration of the city Kolkata, designated as KMA, is located between $88^{\circ} 04^{\prime} \mathrm{E}$ to $88^{\circ} 32^{\prime} \mathrm{E}$ and $23^{\circ} 01^{\prime} \mathrm{N}$ to $22^{\circ} 19^{\prime} \mathrm{N}$ along both banks of the river Hooghly (Fig. 1). It is the third most populous metropolitan area (about 14.06 million population in 2011) in India and accommodates a major share of the urban population of West Bengal [16]. KMA covers an area of 1851.41 sq. $\mathrm{km}$ spread over 6 districts adjacent to the Kolkata city comprising 3 Municipal Corporations, 38 municipalities and 538 towns and villages [17]. KMA is situated the lower part of Ganga-Bhagirathi deltaic plain with elevation ranging between 3.5 and $6 \mathrm{~m}$ from the mean sea level. The area is characterized by many depressions in the form of marshes, shallow wetlands, and ox-bow lakes which are the remnants of the old river channels of Bhagirathi [18]. The deltaic plain is primarily covered by younger alluvial soils, mainly silty and clayey loams, which have been deposited by the rivers throughout the Quaternary [19]. At present, meagre amount of natural vegetation is found in the KMA as the continuous expansion of built-up and cultivated areas have replaced the natural vegetation covers. Vegetation covers including indigenous as well as exotic varieties of fruits, bamboo groves, flowering plants, and scrubs are found around the settlements, agricultural plots, and along the roads. These are the main habitats for the existing faunal biodiversity of the region [20]. The primary crops of KMA are different seasonal varieties of paddy, oilseeds, lentils, jute, and vegetables. Plantation of fruit-bearing trees (mostly mango, guava, banana, and coconut) as well as freshwater aquaculture farms are growing in number and extent during the last few decades here. However, cultivation of vegetables and horticultural activities are more prominent in the urban fringes of Kolkata city [12].

\subsection{Data acquisition}

Four sets of orthorectified Images of Landsat 5 Thematic Mapper (TM) and Landsat 8 Operational Land Imager (OLI) with 10-year intervals (images of 1990, 2000, 2010, and 2020) were downloaded from the United States Geological Survey (USGS) Glovis (http://glovis.usgs.gov) website $[14,15]$ and used for identification of the agricultural changes in KMA (Table 1). All of these images had UTM projection and WGS84 datum [21]. In order to obtain cloud free images ( $<10 \%$ cloud cover), the month of January had been preferred and, accordingly, two scenes had been downloaded for each year to cover the whole study area. In addition, digital elevation model (DEM) data of the Shuttle Radar Topography Mission (SRTM) with $30 \mathrm{~m}$ spatial resolution was also downloaded from the NASA earth data website (http://urs.earthdata.nasa.gov/) to develop the future projected scenario of UPA transformations (Fig. 2). Moreover, the road network data of KMA available from DIVA/GIS (http://www.diva-gis.org/datadown) and rainfall and temperature data of KMA available from APDRC website (http://apdrc.soest.hawaii.edu/) had also been used for this purpose. Urban population density data for each constituent district of KMA for two consecutive census years (2001 and 2011, respectively) were also used to establish the future projected land use scenarios [16]. 
Fig. 1 Location of the study area

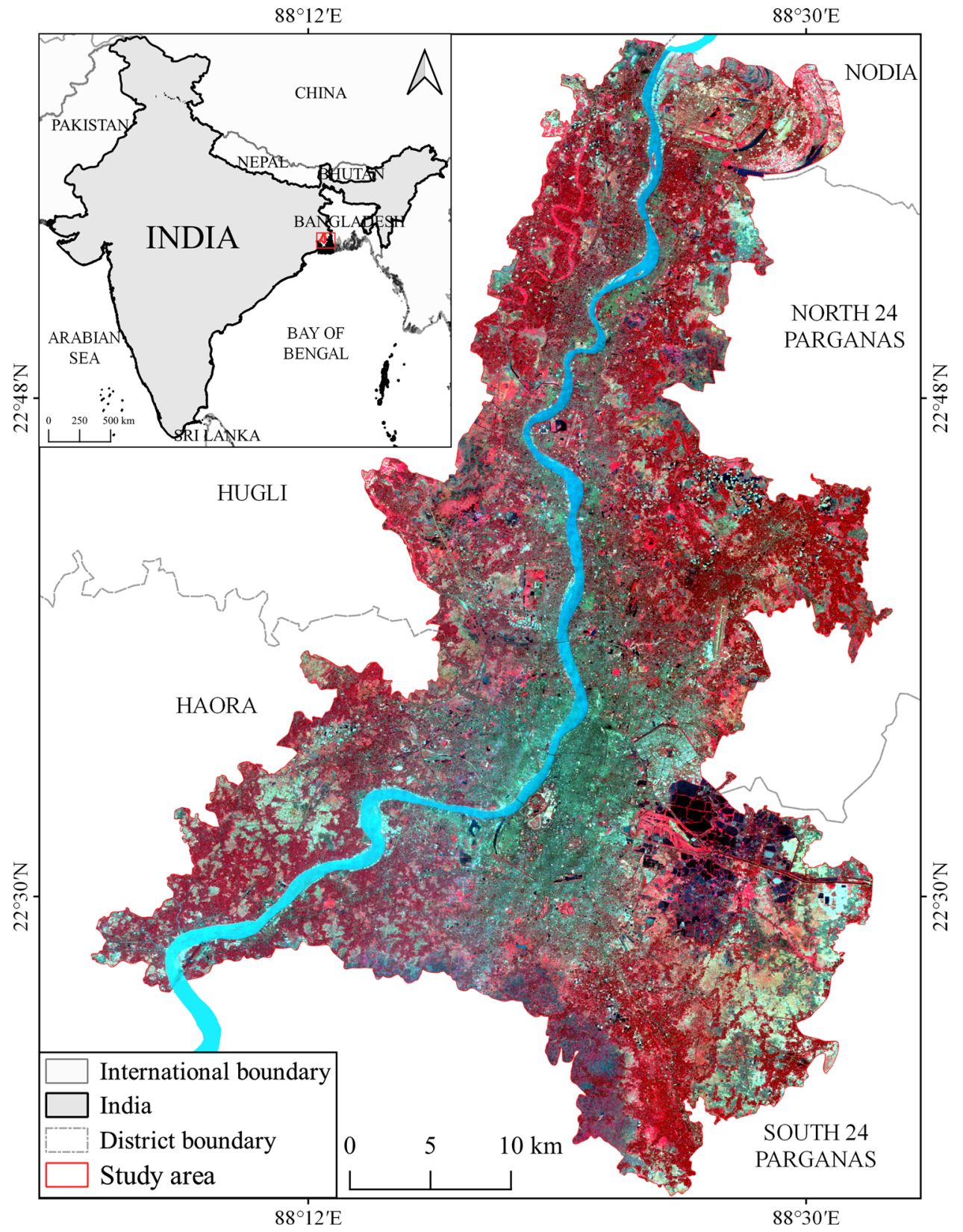

Table 1 Details of satellite images used for LULC classification

\begin{tabular}{|c|c|c|c|}
\hline $\begin{array}{l}\text { Date of Acquisi- } \\
\text { tion }\end{array}$ & Sensor & Path/Row & $\begin{array}{l}\text { Spatial resolution } \\
\text { (m) }\end{array}$ \\
\hline $\begin{array}{l}\text { 30th January } 1990 \\
\text { 14th January } 1990\end{array}$ & \multirow{3}{*}{$\begin{array}{l}\text { Landsat } 5 \text { The- } \\
\text { matic Map- } \\
\text { per (TM) }\end{array}$} & $\begin{array}{l}138 / 44 \\
138 / 45\end{array}$ & \multirow[t]{5}{*}{30} \\
\hline $\begin{array}{l}\text { 26th January } 2000 \\
\text { 26th January } 2000\end{array}$ & & $\begin{array}{l}138 / 44 \\
138 / 45\end{array}$ & \\
\hline $\begin{array}{l}\text { 21th January } 2010 \\
21 \text { th January } 2010\end{array}$ & & $\begin{array}{l}138 / 44 \\
138 / 45\end{array}$ & \\
\hline 17th January 2020 & Landsat 8 & $138 / 44$ & \\
\hline 01th January 2020 & $\begin{array}{l}\text { Opera- } \\
\text { tional Land } \\
\text { Imagery } \\
\text { (OLI) }\end{array}$ & $138 / 45$ & \\
\hline
\end{tabular}

\subsection{Data processing}

Pre-processing of the downloaded images had been conducted in open-source QGIS software version 2.18.23. Multispectral data sets had been prepared by the 'Band Set' process with different band combinations for each of the Landsat $5 \mathrm{TM}$ and Landsat $8 \mathrm{OLI}$ images using the Semi-Automatic Classification Plugin (SCP) of QGIS [22]. Thereafter, geometric corrections were conducted on all data sets having level-I processing [14]. Image georeferencing had been done using 400 ground control points (GCPs) located by GNSS-based surveys (handheld Garmin 12 channel device). These 400 GCPs were collected from 


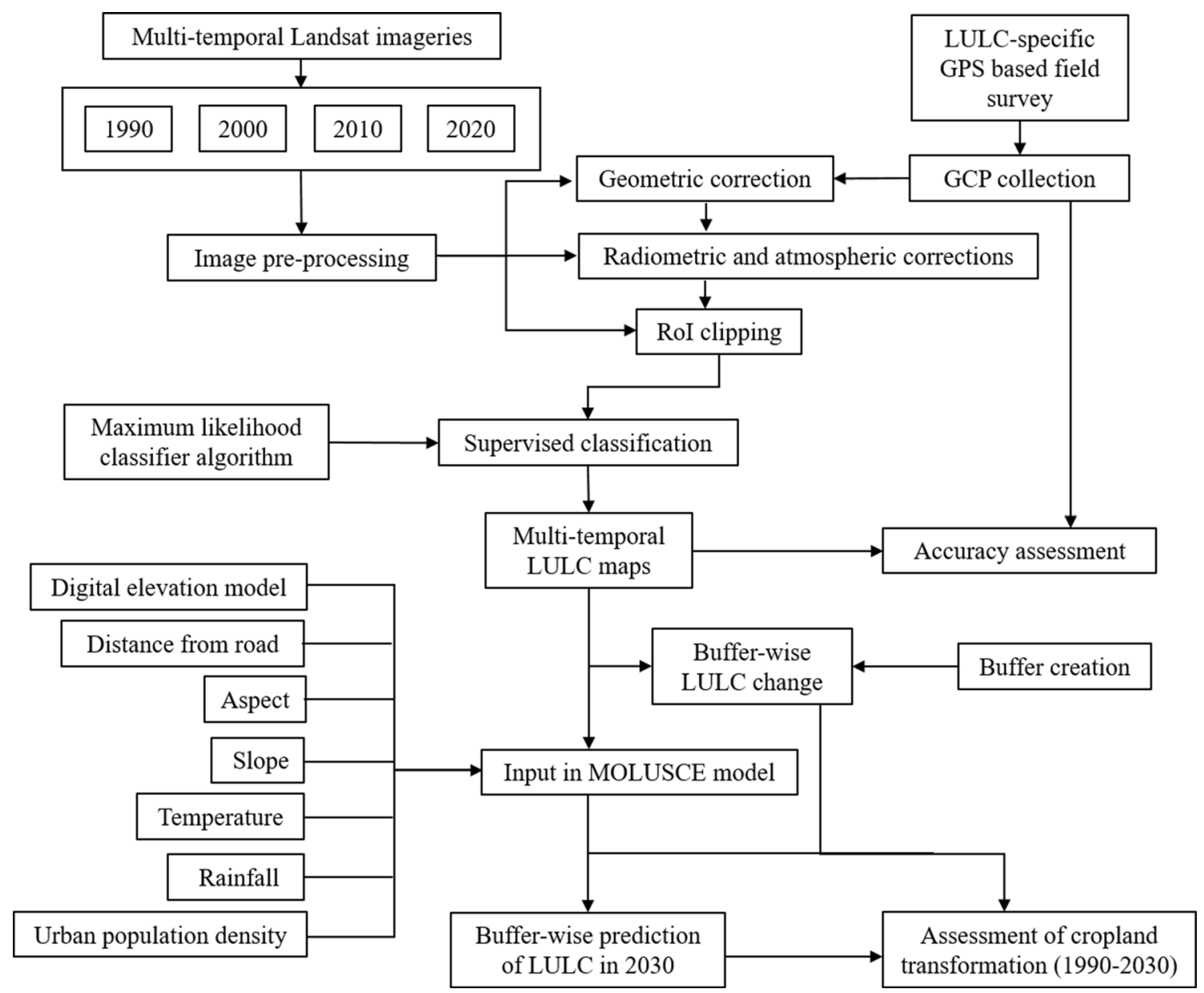

Fig. 2 Methodology of the study. LULC=land use/ land cover; GCP=ground control point; Rol=region of interest; MOLUSCE=Modules for Land Use Change Evaluation

120 plots consisting of various LULC classes identified during pilot-scale field surveys, based on stratified random sampling method. To achieve accurate georeferencing, the root-mean square (RMS) error values of the corrected images for the present study were kept as 0.4 pixels, which was considered to be an acceptable error value [23]. Subsequently, radiometric correction and atmospheric correction were also performed using the SCP-Plugin based on the Dark Object Subtraction (DOS) algorithm, to obtain accurate spectral reflectance values and to remove various noises. Subsequently, corrected sets of multispectral images were mosaicked and the KMA portion was then clipped as the region of interest (Rol) using the clip raster tool.

\subsection{Image classification}

In order to identify the LULC change patterns of KMA from 1990 to 2020, primarily dominant land use or land cover types were classified through supervised classification based on the maximum likelihood algorithm in QGIS [13-15]. Altogether, six major LULC classes were identified for the KMA based on the authors' a priori field experience and high-resolution images of Google Earth geo-visualizer, viz. built-up, wetland, water body, cropland, vegetation, and fallow land. Among these, the cropland class was comprised of agricultural plots with/without crops during the time of image acquisition (month of January). Besides, the fallow land class was primarily constituted with open spaces, playgrounds, industrial fallow, and real-estate plots still kept vacant. The minor extent of area falling under social forestry, parks, and golf course was considered under the vegetation class. However, distinguishing freshwater wetlands (shallow ones, depth $<2 \mathrm{~m}$ ) from water bodies (deeper ones, depth $>2 \mathrm{~m}$ ) was a challenging task [18]. Therefore, land surface features (viz. vegetation) associated with wetlands and water bodies were distinctively recorded during field visits which had been later used in LULC classification. Moreover, spectral signatures of the pixels of both wetlands and water bodies along with the 
changes in tonal quality were considered in the classification to avoid confusion between these two LULC classes. Here, aquaculture plots were considered under water bodies. However, the small concretized pools and reservoirs were classified under built-up area. Several training signatures within the Rol were also collected from standard false color composites for each year based on pixel color, tone, texture, and association to aid the supervised classification procedure $[13,14,21]$. After preparing all LULC maps, accuracy assessments were carried out for each one. For this purpose, SCP tool of QGIS had again been used. LULC patterns of the 120 plots identified during fieldwork and high-resolution Google Earth images were considered as references to validate the classification accuracy. Producer's accuracy, user's accuracy, overall accuracy and Kappa Coefficient were estimated under this assessment procedure.

\subsection{Analysis of inter-class LULC transformation}

A cross tabulation-based method of pixel-to-pixel change had been followed to enumerate the areal transformations of different LULC classes [24, 25]. Initially, three inter-class LULC transformation matrices of successive assessment years (viz. 1990 to 2000, 2000 to 2010, and 2010 to 2020) had been prepared using Modules for Land Use Change Evaluation (MOLUSCE) plugin of QGIS software [15, 22, 26]. Thereafter, another transformation matrix from 2020 to 2030 , i.e. the future predicted year of assessment, was developed based on probabilistic prediction algorithms [22]. In this study, the entire KMA had been subdivided into six concentric zones for the purpose of in-depth analyses of LULC dynamics using the multi-ring buffer tool of QGIS. It had been observed that, in case of Kolkata, the continuous built-up area surrounding the urban core nearly coincides with the boundary of Kolkata Municipal Corporation (KMC). Hence, KMC boundary was considered as the first zone, i.e. core zone. Thereafter, five fixed distance buffers were conceived surrounding the core zone. A conventional value of $10 \mathrm{~km}$ was chosen to create these buffers to grossly examine how and why changes in LULC were happening along different directions in different parts of KMA $[27,28]$. The zones started at the core (Kolkata Municipal Corporation area) and then continued from buffer zone I to buffer zone $V$ towards the periphery of KMA roughly indicating a gradual transition from continuous urban built-ups through urban fringes to rural fringes [11].

\subsection{Projection of future LULC scenario}

The MOLUSCE plugin was again used for projection of the future LULC scenario of KMA in 2030. Seven ancillary variables (DEM, aspect, slope, distance from road, rainfall, temperature, urban population density) were considered in this model to facilitate the projection [15]. Moreover, it was assumed that the pattern of climate change induced agricultural degradation and trends of other environmental factors including soil, water and air pollution would remain almost similar as present in the near future. Among several algorithms available in MOLUSCE, the artificial neural network (ANN) had been preferred for the future scenario projection in this study. In reality, ANN is a nonlinear machine learning algorithm which depends on multiple inputs [26]. DEM, slope and aspect were derived from SRTM elevation data using raster analysis in QGIS. Similarly, raster data sets of monthly average rainfall and temperature of 2010 and 2020 were derived from APDRC website. Urban population density data of census year 2001 and 2011 were used to generate population vector maps for 2010 and 2020, respectively, which were then transformed to raster data format. These raster data sets were then resampled to $30 \mathrm{~m}$ resolution. All these data sets along with the LULC maps of 2020 and 2030 were used as input variables in the MOLUSCE. Spatial distance from the road was calculated by Euclidean metrics based on the DIVA/GISdataset [13, 15, 29]. Firstly, LULC scenario of 2020 was simulated using LULC data of 2000 and 2010 as base years and then validated with reference to the actual LULC map of 2020 as a measure of calibration [15, $22,30]$. Finally, LULC map for the year 2030 was developed by the calibrated system using the actual classified maps of 2010 and 2020, respectively.

\section{Results}

\subsection{Changing LULC scenarios of KMA}

Four maps of LULC of KMA had been prepared with six classes through supervised classification (Fig. 3). During accuracy assessment of the produced maps, the values of Kappa coefficient were found as 0.90 (1990), 0.91 (2000), 0.93 (2010), and 0.92 (2020), respectively. Besides, the overall classification accuracies for these maps were 93.33\% (1990), 94.17\% (2000), 95.00\% (2010), and 95\% (2020), respectively (Table 2). In general, the major areas of confusion and error were in clearly differentiating the wetlands and waterbodies in the urban fringes of eastern and south-eastern parts of KMA.

The LULC scenarios of KMA from 1990 to 2020 portrayed intricate interplay between various land uses and land covers which varied considerably both at temporal and spatial scales. Between the year 1990 and 2000, notable increase in area under built-up and sizeable decrease in cropland had been found in all the zones of KMA (Fig. 3a, b). 


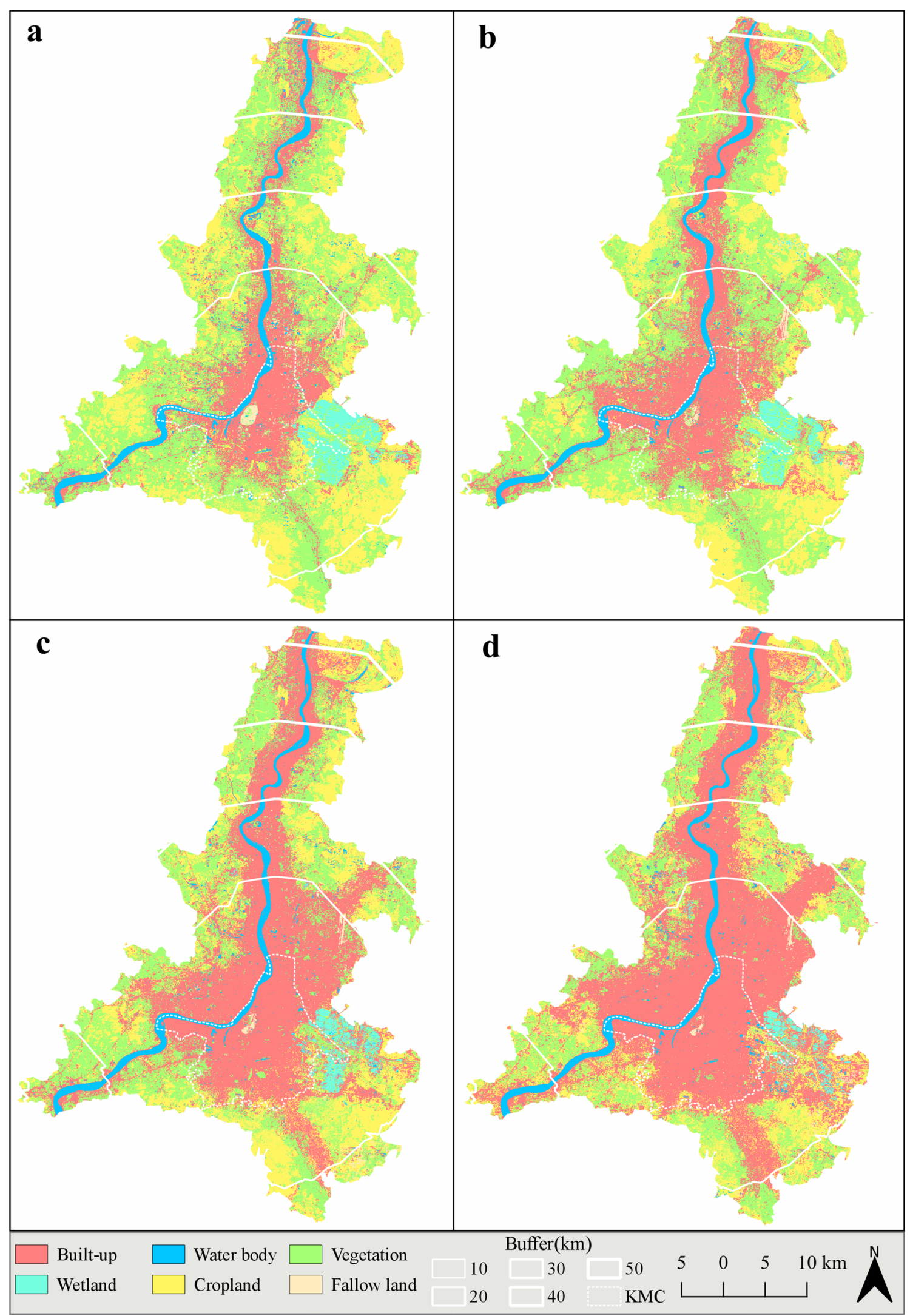

Fig. 3 LULC maps of KMA for a 1990, b 2000, c 2010, d 2020 
Table 2 Accuracy assessment for supervised classifications of satellite images used in the study

\begin{tabular}{llllll}
\hline Year & LULC class & $\begin{array}{l}\text { Producer's } \\
\text { accuracy } \\
(\%)\end{array}$ & $\begin{array}{l}\text { User's } \\
\text { accuracy } \\
(\%)\end{array}$ & $\begin{array}{l}\text { Overall } \\
\text { accuracy }\end{array}$ & $\begin{array}{l}\text { Overall } \\
\text { Kappa } \\
(\mathrm{K} \wedge)\end{array}$ \\
\hline 1990 & Built-up & 100.00 & 83.33 & $93.33 \%$ & 0.9039 \\
& Wetland & 100.00 & 100.00 & & \\
& Water body & 50.00 & 100.00 & & \\
Cropland & 94.87 & 97.37 & & \\
Vegetation & 97.83 & 95.74 & & \\
2000 & Fallow land & - & - & & \\
Built-up & 96.30 & 92.86 & $94.17 \%$ & \\
Wetland & 100.00 & 100.00 & & \\
Water body & 100.00 & 100.00 & & \\
Cropland & 82.35 & 93.30 & & \\
Vegetation & 98.46 & 94.12 & & \\
Fallow land & 33.33 & 100.00 & & \\
2010 & Built-up & 97.78 & 97.78 & $95.00 \%$ & \\
Wetland & 33.33 & 100.00 & & \\
Water body & 100.00 & 100.00 & & \\
Cropland & 86.96 & 95.24 & & \\
Vegetation & 100.00 & 92.86 & & \\
Fallow land & 100.00 & 80.00 & & \\
Built-up & 95.38 & 95.38 & $95.00 \%$ & \\
Wetland & 50.00 & 100.00 & & \\
Water body & 100.00 & 100.00 & & \\
Cropland & 95.24 & 95.24 & & \\
Vegetation & 100.00 & 92.59 & & \\
Fallow land & 100.00 & 100.00 & & \\
\hline
\end{tabular}

Primarily, a north-south-oriented pattern of urban sprawl and emergence of new patches of built-ups were evident which had consumed considerable amount of cropland, wetland, and water body. Growth of new residential sectors to accommodate incessantly growing urban population and development of new industrial clusters had caused fragmentation of the croplands in most of the peri-urban areas. Surprisingly, slight increase in vegetation cover had also occurred in buffer zone I (2.35\%), II (2.85\%), IV (10.23\%), and V (82.89\%) mostly at the cost of existing croplands (Fig. 4). This apparent anomaly to the general trend of LULC change could be explained with the fact that tree plantation and horticultural plots with dense canopy structure were considered as part of vegetation here towards distinct identification of croplands primarily growing staples, ground crops and other vegetables. Thus, growth of vegetation was probably related with the increase in acreage of tree crops during this phase.

All the zones portrayed sharp increase in built-up area and substantial decrease in vegetation area between 2000 and 2010 (Fig. 3b, c). Continued spread of urban built-up had occurred mainly at the cost of vegetation as well as by engulfing croplands, wetlands, and fallow lands particularly in the zones near the urban core. Notably, an increase in area under cropland is found in the regions far from the urban core. For example, buffer zone $\mathrm{V}$ recorded an increase of $3.76 \mathrm{sq}$. $\mathrm{km}$ in cropland in 2010 denoting primarily the conversion from erstwhile vegetation areas of 2000.

Decrease in area under cropland consequent to its conversion into built-ups and fallow lands continued in the period between 2010 and 2020 (Fig. 3c, d). The reduction in croplands was most prominent in the urban fringe areas (buffer zone I and II). The growth of built-ups were overwhelming throughout the KMA. Wetland areas declined considerably in most of the zones during this phase. However, vegetation cover increased from $6.14 \mathrm{sq} . \mathrm{km}$ in 2010 to 8.7 sq. $\mathrm{km}$ in 2020 only in buffer zone V, mostly at the cost of cropland. During field verifications, this was found to be chiefly due to the proliferation of agroforestry activities (viz. Eucalyptus globulus, Acacia auriculiformis and Tectona grandis) and horticultural plantations in the rural fringes of KMA in recent years in place of croplands cultivating staples and jute in earlier phases.

\subsection{Patterns of inter-class LULC transformation}

\subsubsection{Core zone}

Core zone consisted of 144 municipal wards of Kolkata Municipal Corporation (KMC) and represented the most urbanized part of KMA. Since 1990, persistent growth of urban built-ups had continued in this zone by devouring the scattered as well as tiny patches of croplands, wetlands, vegetation, fallow lands etc. A reduction in approximately $10.41 \mathrm{sq} . \mathrm{km}$ in cropland area had occurred between 1990 and 2000 and an area of $29.26 \mathrm{sq}$. km had decreased in vegetation cover between 2000 and 2010 mainly to accommodate urban growth in the form of continuous built-ups (Table 3 and Table 4). In particular, the notably high growth of built-up areas (29.37\%) between 2000 and 2010 had actually jeopardized the existence of almost all other LULCs except the built ones in this zone as wetland and cropland areas reduced by $25.66 \%$ and $26.43 \%$, respectively. This trend also continued in the 2010-2020 phase thereby severely defragmenting the East Kolkata Wetland, a Ramsar site, and its adjoining agricultural plots (Table 5).

\subsubsection{Buffer zone I}

As the urban built-up continued to spread outward, it eventually engulfed the non-urban LULCs lying immediate to the core zone. Thus, the buffer zone I primarily represented the suburban areas which experienced steady 

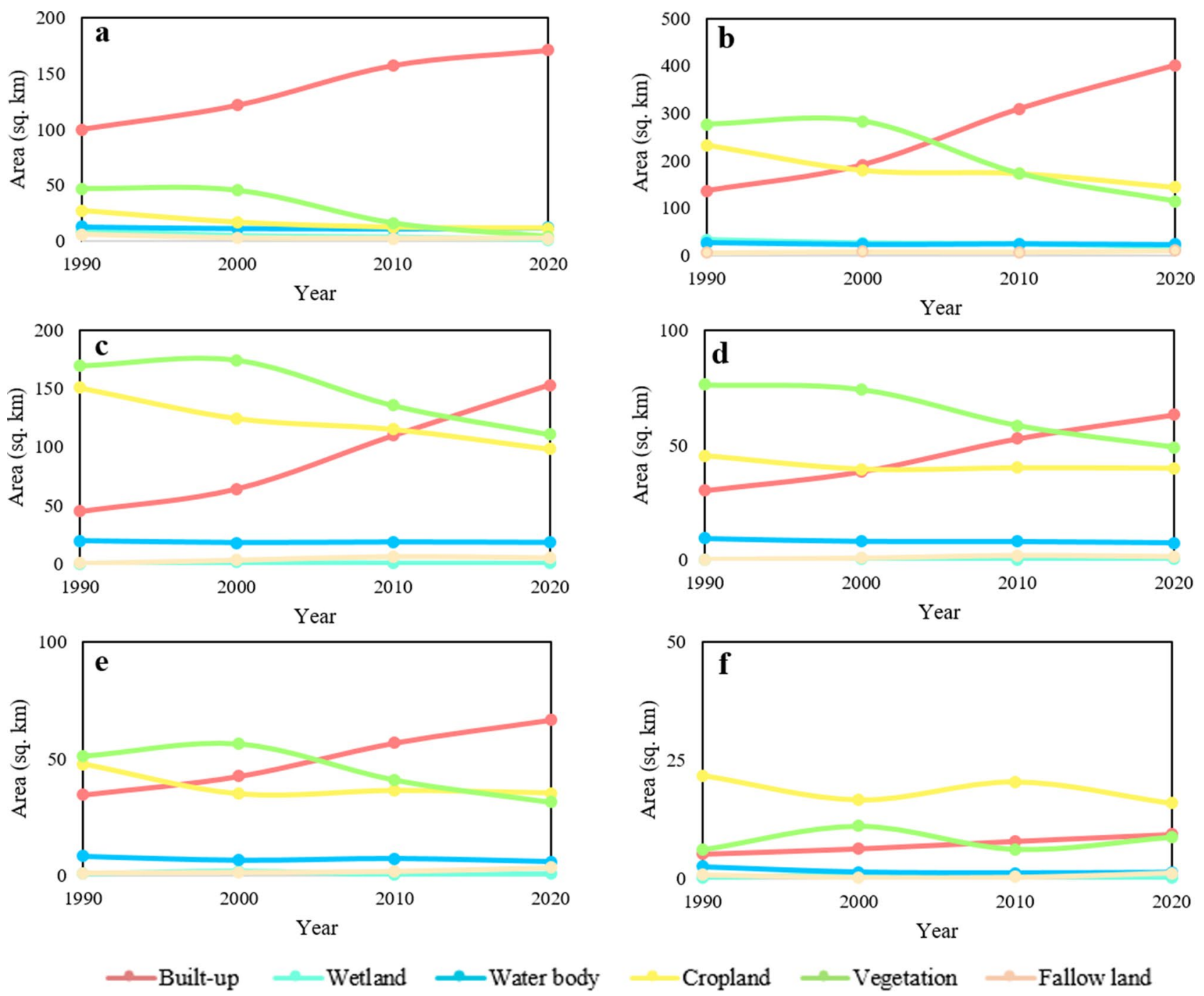

Fig. 4 LULC change scenarios of different zones of KMA from 1990 to 2020. a Core zone, b Buffer zone I, c Buffer zone II, d Buffer zone III, e Buffer zone IV, f Buffer zone V

growth of residential sectors, commercial buildings, industries, IT hubs etc. at the expense of peri-urban croplands, vegetation, and wetlands in the last few decades. Almost $53.36 \mathrm{sq} . \mathrm{km}$ reduction in cropland and $7.11 \mathrm{sq} . \mathrm{km}$ decrease in wetland were observed in response to growth of built-ups (54.83 sq. km) and fallow lands ( $2.24 \mathrm{sq} . \mathrm{km}$ ) between 1990 and 2000. However, highest growth of suburban built-ups (62.13\%) had taken place at the expense of vegetation cover (82.65 sq. $\mathrm{km}$ ) and cropland ( 27.57 sq. $\mathrm{km}$ ) in this zone in the 2000-2010 phase (Table 4). Although vegetation cover generally reduced between 2000 and 2010, croplands of approximately $25.78 \mathrm{sq} . \mathrm{km}$ area were transformed to vegetation chiefly in the form of horticultural tree plantations. Shrinkage of croplands continued in the 2010-2020 period mainly to accommodate built-ups and fallow lands.

\subsubsection{Buffer zone II}

The buffer zone Il denoted the transitional areas between suburban and urban fringe where continued expansion of the built-ups in response to growing urban populace as well as establishment of new industrial, real estate and commercial sectors were taking place through engulfment of peri-urban croplands and vegetated plots. Spread of built-ups along the arterial roads and fragmentation of existing croplands were prominent in this part from 2000 to 2020 . Although cropland showed a steady decline with respect to total area over the entire assessment period, a complex land use transformation dynamics existed between cropland, vegetation, and built-up. For instance, notwithstanding the fact that the total area under cropland had decreased by 16.99 sq.km between 2010 and 


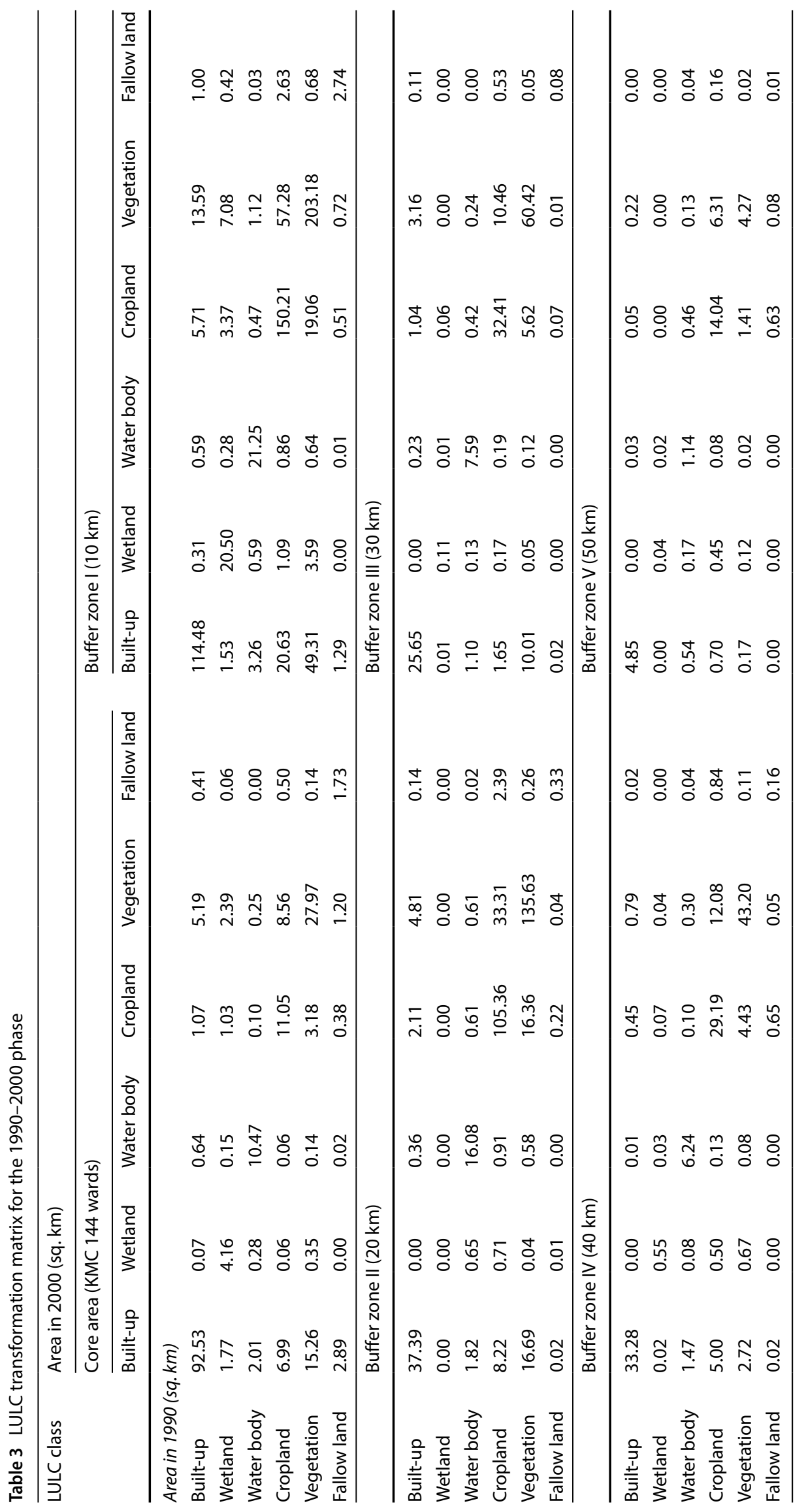




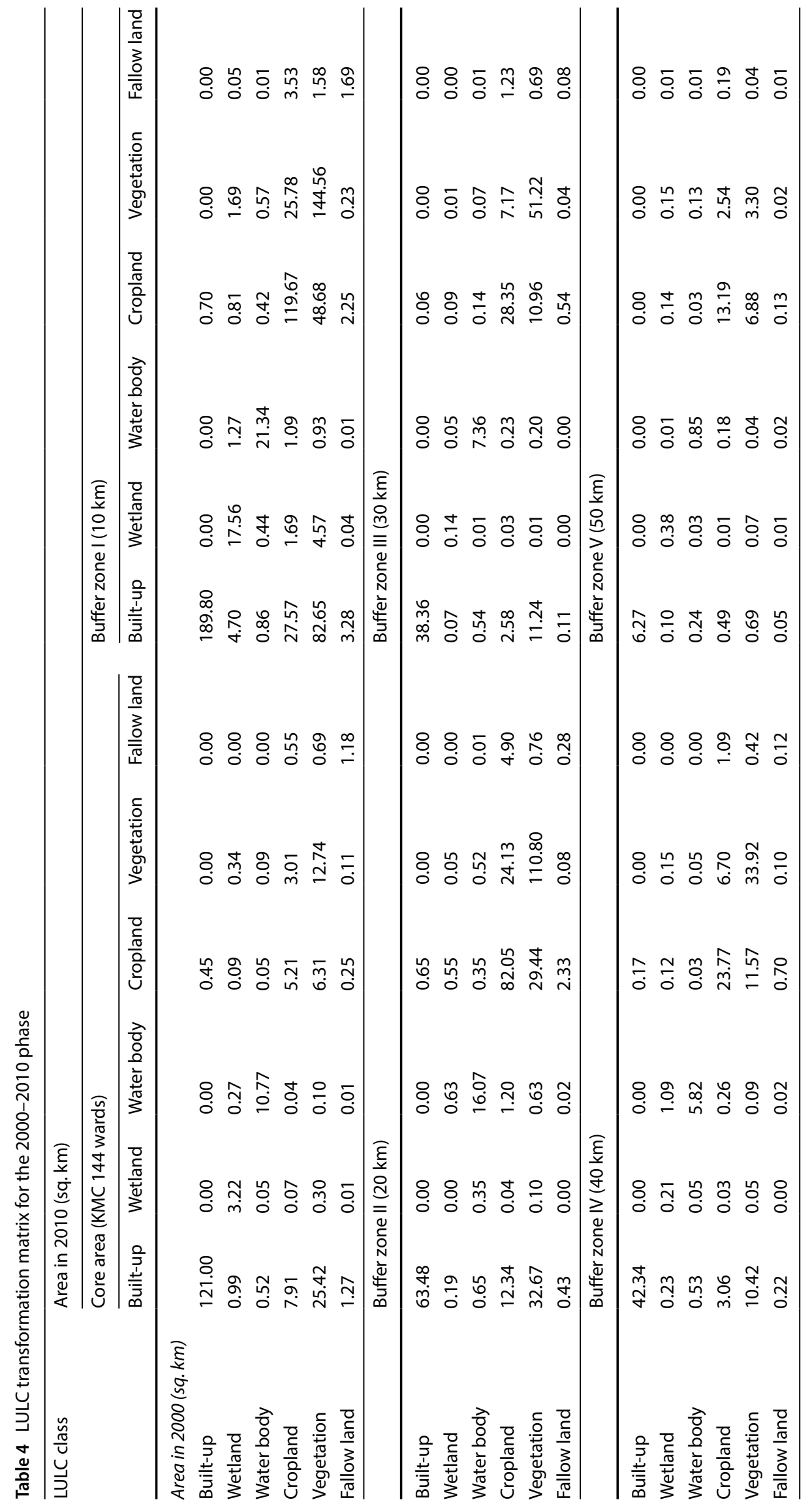




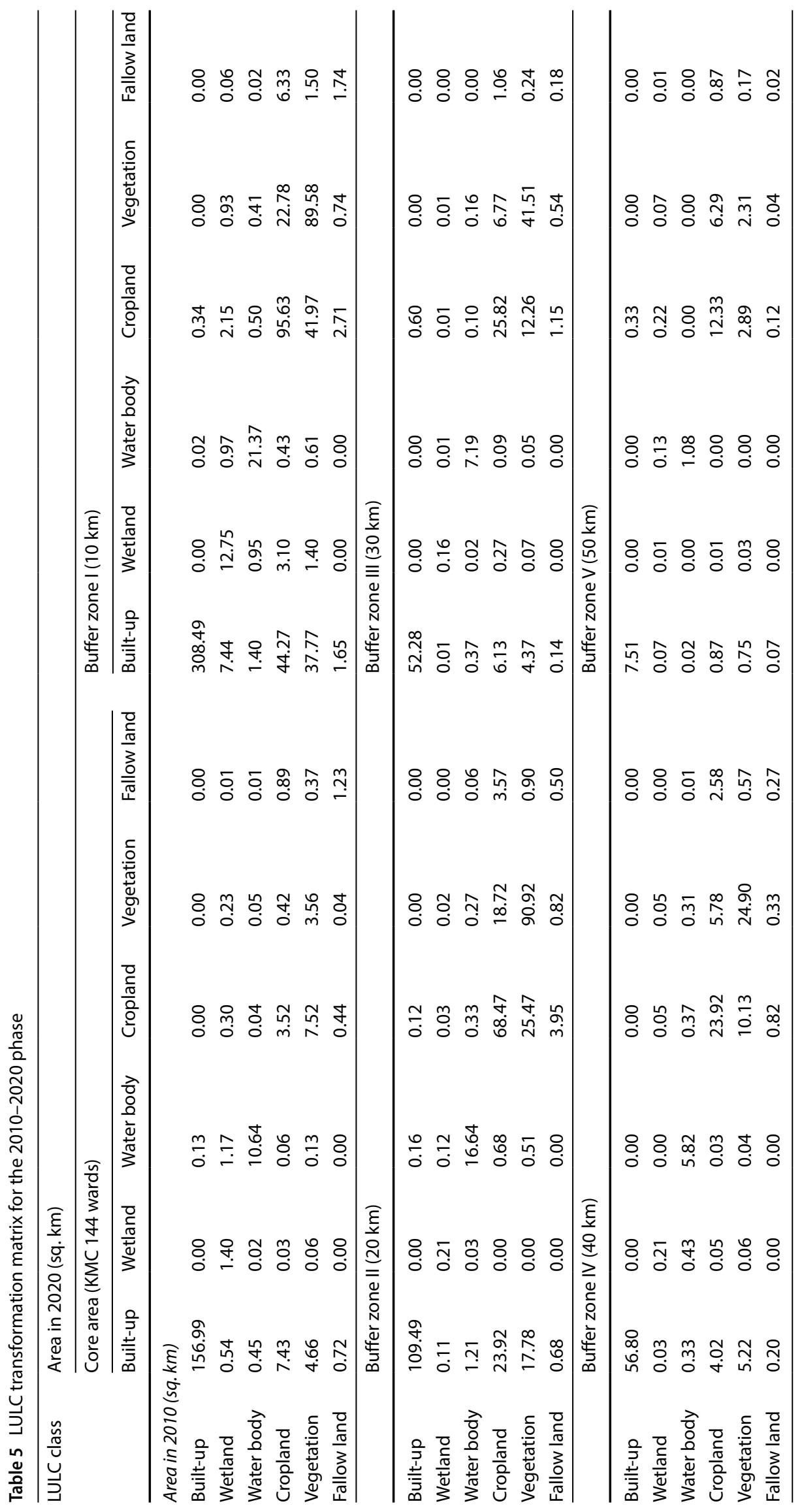


2020 and had been transformed to built-up, vegetation, and fallow land; considerable amount of vegetation had also been transformed into cropland during the same period (Table 5). This may be due to the differential trajectories of land use change where, at one end, built-ups were growing through intake of all other LULC classes; croplands, on the other, were also changing its location and extent by converting newer plots of other land covers like wetland, vegetation, and waterbody. In general, the LULC maps suggested the growth of croplands followed by built-up outward from the core in different phases. Nevertheless, noteworthy amount of cropland still existed in this zone in 2020 especially in the south-western and southeastern parts of KMA.

\subsubsection{Buffer zone III}

The third zone roughly represented the urban fringe areas in most portions of KMA except the northern side along the banks of river Hooghly where suburban characteristics still continued. Despite expansion in built-up areas, substantial amount of croplands also existed in these urban fringes as it lay comparatively far from the urban core. Large amount of croplands had been converted to vegetation (10.46 sq. $\mathrm{km}$ ) and concurrently almost same amount of land under vegetation got converted into builtup (10.01 sq. km) between 1990 and 2000. However, these transformations were not conterminous and spread across KMA. In few areas, croplands gave way to tree plantations and, in others, built-ups engulfed plots covered with natural vegetation. Although conversions from cropland to built-up, vegetation, and fallow land were prominent from 2010 to 2020, overall loss of cropland was only 0.20 sq. km within this zone during this phase as it was counterbalanced by the conversion of vegetation into cropland.

\subsubsection{Buffer zone IV}

This zone had features resembling to that of the transitional areas between urban fringe and rural fringe, an area where the prevalence of urban characteristics gradually diminished and rural characteristics started to become prominent [10].The amount of cropland reduced sharply (26.87\%) between 1990 and 2000 owing to a renewed enthusiasm of the State government towards industrialization. Subsequently, percentage growth of built-up $(33.62 \%)$ was found to be slightly higher in this zone, especially between 2000 and 2010 . In spite of relatively greater distance from the urban core, the growing demand of green-field sites for new commercial and industrial clusters had actually triggered the rampant acquisition of croplands in the central-western and eastern parts of this zone. Substantial amount of reduction in area (27.53\%) under vegetation had also occurred during the 2000-2010 phase. Cropland, water body and vegetation cover also decreased in area from 2010 to 2020 to accommodate growth of built-up as well as fallow land. Here, a characteristically slow but steady growth of fallow land was also observed which might get converted into built-ups in the imminent years.

\subsubsection{Buffer zone V}

Located afar from the urban core, this zone portrayed the rural fringe features with relatively slow growth of built-ups. Nevertheless, intricate inter-class conversions and resultant fluctuations in area of various LULC classes had been found here over the entire assessment period. This zone witnessed loss of notable amount of area under cropland (5.13 sq. km) which was mostly converted into vegetation in the form of agroforestry farms between 1990 and 2000 . Few water bodies of this area were also converted for this purpose. This scenario almost reversed in the 2000-2010 phase when noteworthy increase in area under cropland (10.40\%) in expense of natural vegetation was recorded. Similar to the scenario of buffer zone III, these transformations of the two assessment phases (1990-2000 and 2000-2010) were not conterminous. This reversal might be ascribed to the augmenting urban food demand and consequent search for new plots of agriculture. However, the land use dynamics again changed and started to follow the trend of other interior buffer zones in the 2010-2020 phase as area under cropland reduced from 20.37 to $15.88 \mathrm{sq} . \mathrm{km}$ in response to growth of fallow lands and built-ups. Probably, the growth trend of croplands had shifted to the immediate outer areas of zone $V$, outside the formal boundary of KMA, during this phase.

\subsection{Projected future scenario of UPA transformation}

The LULC scenario of KMA in 2030 had been projected through a multi-parameter model. The projected scenario indicated towards continuous growth of built-ups and concomitant reduction in area under other LULCs in all the zones except buffer zone V (Fig. 5). In this outermost zone of KMA, minute positive growth of built-up (1.88 sq. $\mathrm{km}$ ) and cropland (0.69 sq. $\mathrm{km}$ ) with respect to those of 2020 might be observed (Table 6). The growth of cropland in this zone might be attributed to the growing demand of food in the urban market. However, this growth would take place by devouring other non-built land uses as the spread of built-up, even engulfing existing croplands, would be inevitable if the current trend of land market scenario continues. The future prediction scenario of UPA transformation for all the zones of 
Fig. 5 Projected LULC scenario of KMA in 2030

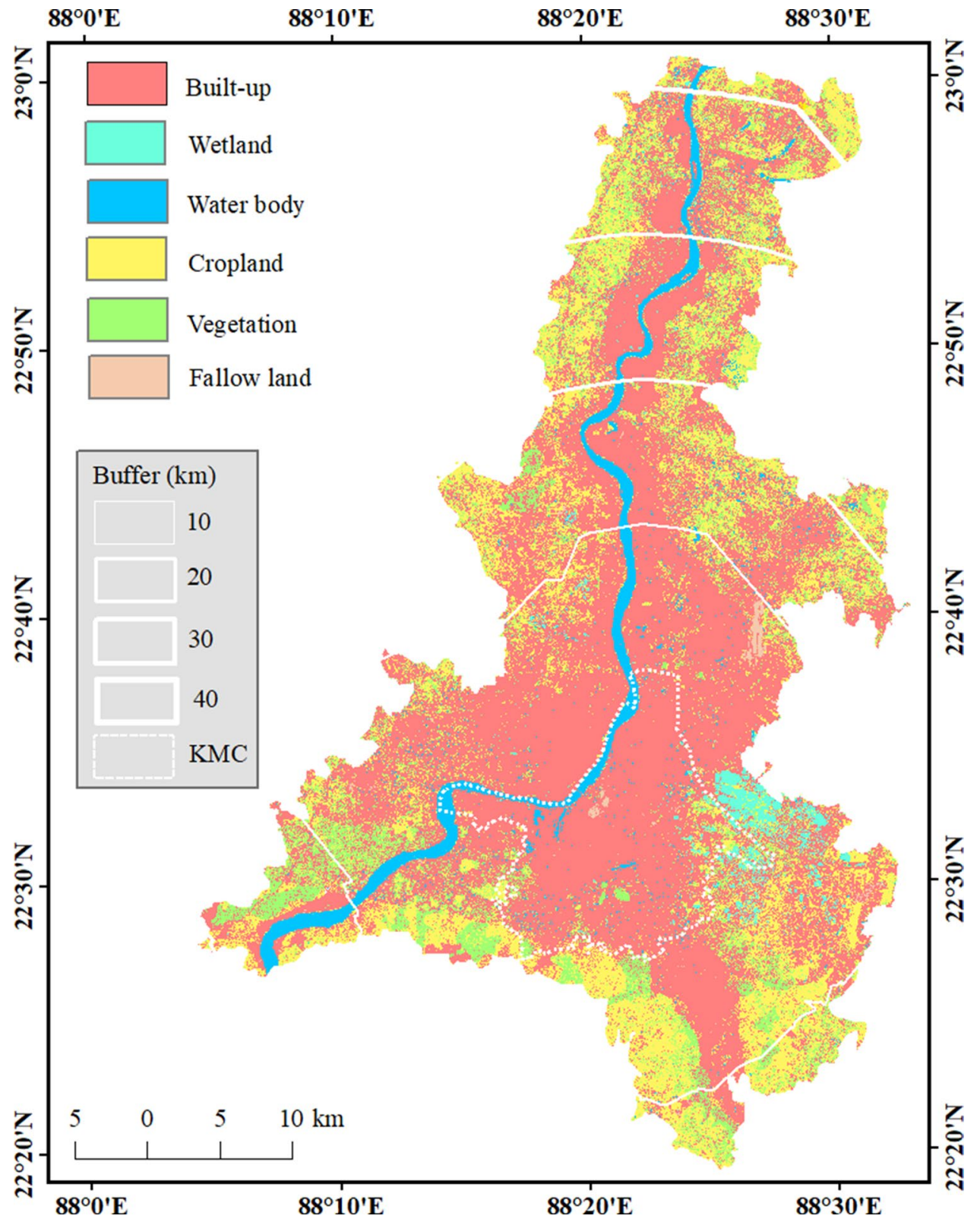

KMA, therefore, indicated that the growth of built-up in greater extent and cropland in lesser extent would continue unabated but their intensities as well as locations of engulfment of other land uses would be different. Even very near to the urban core, i.e. in zone I and II, considerable amount of cropland (135.54 sq. km and 98.04 sq. $\mathrm{km}$, respectively) would still persist in 2030. Conversely, at the outermost zone of KMA, approximately $45.77 \%$ of the total land would remain as cropland irrespective of inter-class transformations from the 2020 scenario (Table 7). This clearly denoted that although urban expansion would be inevitable, peri-urban crop lands would continue to survive for next few years in the expense of other relatively more natural LULC classes (wetland, vegetation and water body) in a competitive land market.

\section{Discussion}

In consideration with the observed and projected trends of LULC transformation in KMA, an increase in the built-ups could be primarily attributed to the decrease in croplands and vegetated areas. In reality, the interplay of several factors such as population growth, resultant expansion of built-ups, land market economics, lack of appropriate environmental conservation policies, and lacklustre implementation of existing protective legal measures 
Table 6 LULC statistics for the projected scenario of 2030

\begin{tabular}{|c|c|c|c|c|}
\hline \multirow[t]{2}{*}{ LULC class } & \multicolumn{2}{|c|}{ Core area (KMC 144 wards) } & \multicolumn{2}{|c|}{ Buffer zone I (10 km) } \\
\hline & Area (sq. km) & Area (\%) & Area (sq. km) & Area (\%) \\
\hline Built-up & 173.74 & 85.57 & 436.04 & 61.41 \\
\hline Wetland & 1.52 & 0.75 & 16.73 & 2.36 \\
\hline Water body & 11.64 & 5.73 & 21.77 & 3.07 \\
\hline Cropland & 8.58 & 4.23 & 135.55 & 19.09 \\
\hline Vegetation & 3.88 & 1.91 & 91.87 & 12.94 \\
\hline \multirow[t]{2}{*}{ Fallow land } & 3.69 & 1.82 & 8.06 & 1.14 \\
\hline & \multicolumn{2}{|c|}{ Buffer zone II (20 km) } & \multicolumn{2}{|c|}{ Buffer zone III (30 km) } \\
\hline Built-up & 181.05 & 46.94 & 74.26 & 45.96 \\
\hline Wetland & 0.16 & 0.04 & 0.29 & 0.18 \\
\hline Water body & 15.88 & 4.12 & 7.34 & 4.54 \\
\hline Cropland & 98.04 & 25.42 & 35.80 & 22.16 \\
\hline Vegetation & 86.17 & 22.34 & 42.61 & 26.37 \\
\hline \multirow[t]{2}{*}{ Fallow land } & 4.39 & 1.14 & 1.26 & 0.78 \\
\hline & \multicolumn{2}{|c|}{ Buffer zone IV (40 km) } & \multicolumn{2}{|c|}{ Buffer zone V (50 km) } \\
\hline Built-up & 77.37 & 53.98 & 11.17 & 30.86 \\
\hline Wetland & 0.51 & 0.36 & 0.04 & 0.11 \\
\hline Water body & 5.01 & 3.50 & 1.22 & 3.37 \\
\hline Cropland & 34.60 & 24.14 & 16.57 & 45.77 \\
\hline Vegetation & 23.40 & 16.33 & 6.59 & 18.20 \\
\hline Fallow land & 2.43 & 1.70 & 0.61 & 1.69 \\
\hline
\end{tabular}

had substantially affected the transformation of UPA in KMA [31]. An unjust trade-off between maintenance of cropland cum other non-built land uses and escalating consumption of land by the urban-industrial sectors was found to be continuing in a relentless manner under a laissez-faire economy in this part of the developing world [32]. However, considerable spatio-temporal heterogeneity among the drivers of land use transformation across KMA had been identified in this study. Few of these drivers were operating as 'facilitators' while others as 'barriers' with respect to the sustenance of land under agriculture.

The UPA sites of inner buffer zones (viz. zone I, II, and partially III) of KMA produced vegetables in general and organic crops in few places based on proximity to major urban markets, export demands, and accessibility of cheap resources such as organic manures and waste water [33]. It played a major role to supplement the daily need of fresh vegetable posed by the urban dwellers. During the lean pre-monsoon season (March-May), lesser supply of the perishable food crops from far-off rural hinterlands was often compensated by these peri-urban croplands due to their nearness and relatively greater availability of infrastructural facilities and technological know-how [33]. Besides, production of rice through subsistence farming was also common in all of the five buffer zones of KMA and it chiefly ensured the food security of the socio-economically marginalized peri-urban communities living here [31]. The spatial distribution of croplands and their production patterns were also found to be depending on the availability of irrigation water. While the availability of organic solid wastes and waste water through canal network facilitated crop production in the inner zones, the peripheral parts were characterized by the extensive use of motorized well jet pumps extracting from the shallow groundwater tables [18]. All of these drivers could be considered as facilitators of UPA in KMA.

There also existed a number of barriers which challenged the very existence of UPA. Continuous population growth and accelerated land demand for the development of new residential areas and infrastructural development resulted into exponential increase in land price [10]. Under such a lucrative land trading market, the periurban landholders, primarily farmers, were found to sell out their lands to the real-estate agencies and industrial enterprises at profitable prices and consequently accelerating the land conversion process. However, the nature of this profit was essentially short-term as the market economy-based financial system did not ensure higher returns of monetary deposits in the long-run [32]. Further, the absence of appropriate government policies to safeguard 


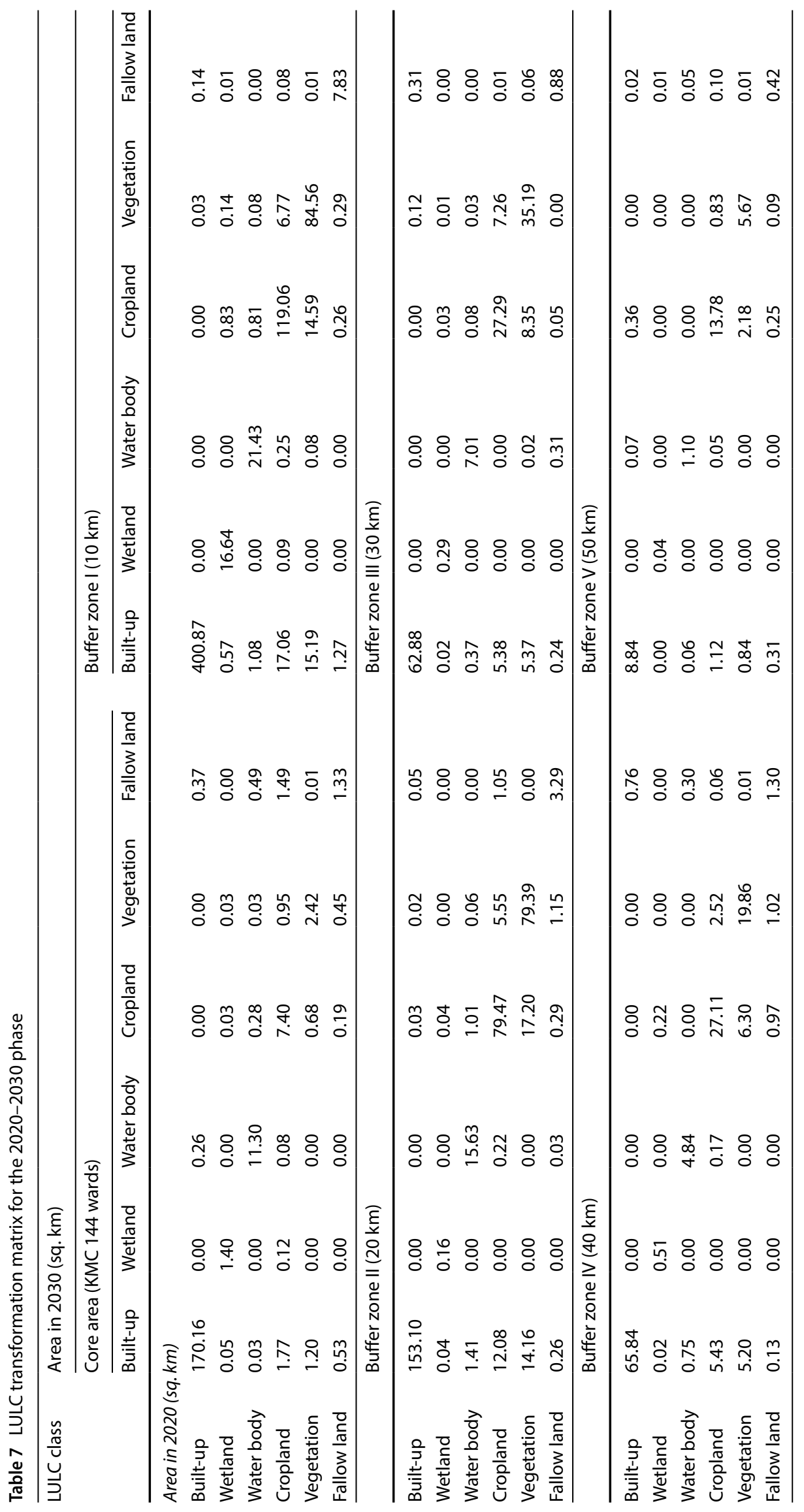


the non-built land uses in peripheral areas, lack of necessary technical and economic assistances to the farmers, unavailability of basic infrastructure for commercial mixed farming and organic practices, increasing environmental threats such as soil and water pollution, ever diminishing status of soil fertility, dearth of irrigation water etc. were continuously endangering the UPA practices in KMA [31]. As a result, the croplands were gradually becoming more economically unsustainable as well as susceptible to land use conversions. For instance, the expansion of national and state highways had stimulated the process of suburbanization in the northern, western, south-eastern, and eastern parts (zone I-IV) of KMA since the mid-1990s [9]. Subsequently, both the public and private real-estate agencies had purchased the croplands adjacent to these highways in anticipation of higher economic returns in imminent future. These parts of the study area had actually witnessed a flurry of built-up expansions including truck terminals, logistic hubs, industrial clusters, large housing complexes and gated residential societies in the last two decades [12]. Further, an alarming shift from small-scale multi-cropping to commercial aquaculture had been observed in the southern and south-eastern parts (zone V) of the study area in particular during the field surveys that had made the regional economy more monopolized under large capital as well as the environment less sustainable. Furthermore, the amount of water bodies and wetlands had declined considerably, which would certainly pose serious ecological problems and render the remaining agroecosystems of KMA more vulnerable in the long-term.

The LULC dynamics and associated transformations in UPA practices had varied spatio-temporally depending on the complex interactions of these facilitators and barriers of land use change. As the detrimental drivers were quantitatively more and their magnitude also aggravated substantially during the assessment years, an overall reduction in croplands had been recorded from 1990 (525.71 sq. km) to 2020 (334.01 sq. km) in KMA. In general, a distinct pattern of land use conversion and loss of croplands had been identified from this study and subsequently structured as a three-stage theoretical model (Fig. 6). At the initial stage of this model, the natural vegetation, wetland and water bodies of the suburbs and urban fringes would be gradually engulfed by agriculture and allied practices. These croplands, tree plantations (including horticulture) and aquaculture ponds would later either temporarily remain as fallow lands owing to the law of diminishing agricultural returns (inner zones) or be converted into scattered

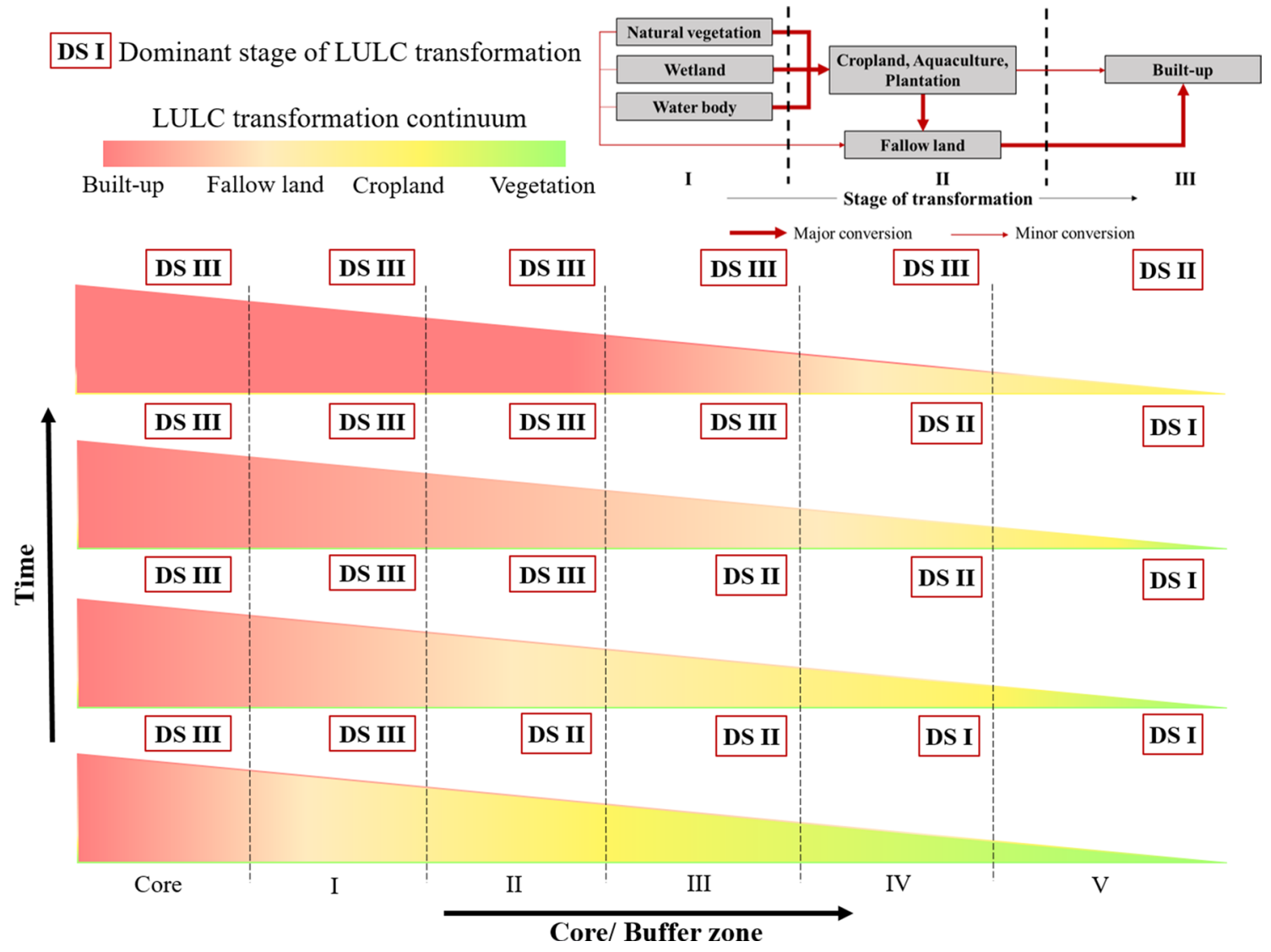

Fig. 6 A three-stage modelling of LULC change trajectories of KMA 
built-ups succumbing to the pressure of increasing land rent (zone IV and V). In few instances, the naturally vegetated and watered areas would be directly reclaimed and transformed into fallow lands for future built-up expansions, mostly in the inner buffer zones of I, II and III. In a free market economy with minimum governmental control like the existing one, the third stage would be characterized by the overwhelming continuous built-up surfaces across KMA. The process of conversions would start at the immediate peripheries of the core city and then spread outward in all directions differentially with respect to the location-specific interactions of the facilitators and barriers. However, it was realized from field verifications that the duration of these intermediate transitional stages were often less than the temporal resolution adopted in the study (i.e. 10 years) and hence were not always truly portrayed in the LULC dynamics of each conceived zone. The outcomes of the projected LULC scenario of 2030, developed in this study, almost matched with the trends of this model and thus could be considered as a validation of the same. Accordingly, comprehensive management strategies should be enacted towards sustenance of the remaining UPA sites of KMA and mitigating the threat of obliteration of greeneries in the near future as inferred by the projected scenario as well as the developed model of land use conversion. Some of the necessary measures to be implemented immediately in this context contained rejuvenation of freshwater and wastewater canals, promotion of agro-forestry in places like Gayeshpur (northern part) and Baruipur (south-eastern part), and agro-tourism in Hugli-Chinsurah (north-western part) and Baruipur, spread of organic farming practices, and reintroduction of integrated freshwater paddy cum fish culture in the southwestern parts of KMA. In addition, formulation and implementation of proper policies to restrict unplanned conversion of UPA land parcels to other non-ecological uses and development of land inventories should go simultaneously through grass-root level awareness campaigning especially among the farmers and fishermen.

\section{Conclusions}

The study revealed a pattern of continuous urban expansion, mostly in northern, eastern, and south-eastern parts of KMA, through persistent increase in the builtup areas during the entire assessment period. Without positive governmental interventions towards sustainable development, regulated land market and community awareness, management of these fragile agroecosystems will become increasingly difficult. If the present socioeconomic framework and administrative mechanism continue in a business as usual orientation, the ecological future of KMA may become severely vulnerable in absence of greeneries and other natural areas within the cityscape.

In a nutshell, the present study made a novel attempt to assess the changes in LULC patterns with respect to UPA transformations of KMA using open-source multitemporal data as well as FOSS and thereby compared the empirical findings with a theoretical model developed in the course of the study notwithstanding a few limitations. The use of Landsat images with relatively coarser spatial resolution certainly remained as one of such limitations. Besides, identification of the LULC classes was based on a few training sites, and accordingly spatial and spectral signatures of those sites might not exactly match throughout the study area. Therefore, application of more sophisticated model of land use conversion considering greater number of predictive variables would certainly provide better estimation of the change trajectory of LULC transformations and enhance the possibilities of managing these fragile agroecosystems of KMA in a sustainable manner in the imminent years.

Acknowledgements We are thankful to the farmers, government officials, and environmental activists for providing relevant information and assistance during the field surveys.

Author contributions This study was conceptualized and designed by Ms. Shrabana Mazumder and Dr. Debajit Datta. The data collection and field surveys were performed by Dr. Debajit Datta, Ms. Mrinmoyee Naskar, Mr. Gournaga Nandi and Mr. Jibananda Gayen. The maps and data tables were prepared by Mr. Gournaga Nandi, Ms. Shrabana Mazumder, Mr. Jibananda Gayen and Ms. Mrinmoyee Naskar. Development of the land use model was performed by $\mathrm{Mr}$. Gournaga Nandi, Dr. Joydeep Saha, and Dr. Debajit Datta. The main text was written by Dr. Joydeep Saha, Ms. Mrinmoyee Naskar, Mr. Jibananda Gayen, Ms. Shrabana Mazumder and Dr. Debajit Datta with equal contributions.

Funding The Corresponding Author received financial assistance from the University Grants Commission (UGC), India in the form of a UGC-BSR sponsored Research Project (No.F.30-380/2017 (BSR)) as the Principal Investigator. This study is part of that major research project.

Data availability Several multispectral satellite images of Landsat series with $30 \mathrm{~m}$ spatial resolution were downloaded from the open access web portal of http://glovis.usgs.gov, http://urs.earthdata.nasa. gov/, http://www.diva-gis.org/datadown, http://apdrc.soest.hawai i.edu/, https://censusindia.gov.in/. Apart from that, the other database of the research is tabulated and provided in processed format within the main text.

Code availability Geospatial applications were performed using the open-source QGIS software version 2.18.23. Specifically, the land use scenario projection was conducted by the Modules for Land Use Change Evaluation (MOLUSCE) plugin. 


\section{Compliance with ethical standards}

Conflicts of interest The authors declare that they have no conflict of interest while conducting and publishing the research work.

Open Access This article is licensed under a Creative Commons Attribution 4.0 International License, which permits use, sharing, adaptation, distribution and reproduction in any medium or format, as long as you give appropriate credit to the original author(s) and the source, provide a link to the Creative Commons licence, and indicate if changes were made. The images or other third party material in this article are included in the article's Creative Commons licence, unless indicated otherwise in a credit line to the material. If material is not included in the article's Creative Commons licence and your intended use is not permitted by statutory regulation or exceeds the permitted use, you will need to obtain permission directly from the copyright holder. To view a copy of this licence, visit http://creativecommons .org/licenses/by/4.0/.

\section{References}

1. Aubry C, Ramamonjisoa J, Dabat MH, Rakotoarisoa J, Rakotondraibe J, Rabeharisoa $L$ (2012) Urban agriculture and land use in cities: an approach with the multi-functionality and sustainability concepts in the case of Antananarivo (Madagascar). Land Use Pol 29(2):429-439. https://doi.org/10.1016/j.landusepol .2011.08.009

2. La Rosa D, Barbarossa L, Privitera R, Martinico F (2014) Agriculture and the city: a method for sustainable planning of new forms of agriculture in urban contexts. Land Use Pol 41:290-303. https://doi.org/10.1016/j.landusepol.2014.06.014

3. Pribadi DO, Pauleit S (2015) The dynamics of peri-urban agriculture during rapid urbanization of Jabodetabek Metropolitan Area. Land Use Pol 48:13-24. https://doi.org/10.1016/j.landu sepol.2015.05.009

4. Fazal S (2000) Urban expansion and loss of agricultural landa GIS based study of Saharanpur city, India. Environ Urban 12(2):133-149. https://doi.org/10.1177/095624780001200211

5. Badami MG, Ramankutty N (2015) Urban agriculture and food security: a critique based on an assessment of urban land constraints. Glob Food Secur 4:8-15. https://doi.org/10.1016/j. gfs.2014.10.003

6. de Zeeuw H, Van Veenhuizen R, Dubbeling M (2011) The role of urban agriculture in building resilient cities in developing countries. J Agric Sci 149(S1):153-163. https://doi.org/10.1017/ S0021859610001279

7. Peng J, Liu Z, Liu Y, Hu X, Wang A (2015) Multifunctionality assessment of urban agriculture in Beijing city, China. Sci Total Environ 537:343-351. https://doi.org/10.1016/j.scito tenv.2015.07.136

8. Tsuchiya K, Hara Y, Thaitakoo D (2015) Linking food and land systems for sustainable peri-urban agriculture in Bangkok Metropolitan Region. Landsc Urban Plan 143:192-204. https://doi. org/10.1016/j.landurbplan.2015.07.008

9. Sharma R, Chakraborty A, Joshi PK (2015) Geospatial quantification and analysis of environmental changes in urbanizing city of Kolkata (India). Environ Monit Assess 187(1):1-12. https://doi. org/10.1007/s10661-014-4206-7

10. Narain V (2009) Growing city, shrinking hinterland: land acquisition, transition and conflict in peri-urban Gurgaon, India. Environ Urban 21(2):501-512. https://doi.org/10.1177/0956247809 339660

SN Applied Sciences

APRINGER NATURE journa
11. Ramachandra TV, Aithal BH, Sowmyashree MV (2014) Urban structure in Kolkata: Metrics and modelling through geo-informatics. Appl Geomat 6(4):229-244. https://doi.org/10.1007/ s12518-014-0135-y

12. Mandal J, Ghosh N, Mukhopadhyay A (2019) Urban growth dynamics and changing land-use land-cover of megacity Kolkata and its environs. J Indian Soc Remote Sens 47(10):17071725. https://doi.org/10.1007/s12524-019-01020-7

13. Addae B, Oppelt N (2019) Land-use/land-cover change analysis and urban growth modelling in the Greater Accra Metropolitan Area (GAMA). Ghana Urban Sci 3(1):1-20. https://doi. org/10.3390/urbansci3010026

14. Boakye E, Anyemedu FOK, Quaye-Ballard JA, Donkor EA (2020) Spatio-temporal analysis of land use/cover changes in the Pra River Basin Ghana. Appl Geomat 12(1):83-93. https://doi. org/10.1007/s12518-019-00278-3

15. Rahman MTU, Tabassum F, Rasheduzzaman M, Saba H, Sarkar L, Ferdous J, Syed ZU, Islam AZMZ (2017) Temporal dynamics of land use/land cover change and its prediction using CAANN model for southwestern coastal Bangladesh. Environ Monit Assess 189(11):1-18. https://doi.org/10.1007/s1066 1-017-6272-0

16. Government of India (2020). A-4 towns and urban agglomerations classified by population size class in 2011. https://censu sindia.gov.in/2011 census/PCA/A4.html. Accessed 17 Jan 2020

17. Bhatta $B$ (2012) Urban growth analysis and remote sensing: $a$ case study of Kolkata, India 1980-2010. Springer, Dordrecht. https://doi.org/10.1007/978-94-007-4698-5

18. Mukherjee S, Bebermeier W, Schütt B (2018) An overview of the impacts of land use land cover changes (1980-2014) on urban water security of Kolkata. Land 7(3):1-25. https://doi. org/10.3390/land7030091

19. Mohanty WK, Verma AK, Vaccari F, Panza GF (2013) Influence of epicentral distance on local seismic response in Kolkata City, India. J Earth Syst Sci 122(2): 321-338.https://doi.org/https:// doi.org/10.1007/s12040-013-0275-1

20. Ghosh S (2010) Urban biodiversity of Calcutta: flowering plants, butterflies, birds, and mammals, West Bengal, India. Zoological Survey of India, Kolkata

21. Satya BA, Shashi M, Deva P (2020) Future land use land cover scenario simulation using open source GIS for the city of Warangal, Telangana, India. Appl Geomat. https://doi.org/10.1007/ s12518-020-00298-4

22. Guidigan MLG, Sanou CL, Ragatoa DS, Fafa CO, Mishra VN (2019) Assessing land use/land cover dynamic and its impact in Benin republic using land change model and $\mathrm{CCl}-\mathrm{LC}$ products. Earth Syst Environ 3(1):127-137. https://doi.org/10.1007/s4174 8-018-0083-5

23. Shalaby A, Tateishi R (2007) Remote sensing and GIS for mapping and monitoring land cover and land-use changes in the Northwestern coastal zone of Egypt. Appl Geogr 27(1):28-41. https://doi.org/10.1016/j.apgeog.2006.09.004

24. Coppin P, Jonckheere I, Nackaerts K, Muys B, Lambin E (2004) Digital change detection methods in ecosystem monitoring: a review. Int J Remote Sens 25(9):1565-1596. https://doi. org/10.1080/0143116031000101675

25. Disperati L, Virdis SGP (2015) Assessment of land-use and landcover changes from 1965 to 2014 in Tam Giang-Cau Hai Lagoon, central Vietnam. Appl Geogr 58:48-64. https://doi.org/10.1016/j. apgeog.2014.12.012

26. Perović $\mathrm{V}$, Jakšić $\mathrm{D}$, Jaramaz $\mathrm{D}$, Koković $\mathrm{N}$, Čakmak D, Mitrović M, Pavlović P (2018) Spatio-temporal analysis of land use/land cover change and its effects on soil erosion (Case study in the Oplenac wine-producing area, Serbia). Environ Monit Assess 190(11):1-18. https://doi.org/10.1007/s10661-018-7025-4 
27. Liu P, Jia S, Han R, Liu Y, Lu X, Zhang H (2020) RS and GIS supported urban LULC and UHI change simulation and assessment. J Sens 2020:1-17. https://doi.org/10.1155/2020/5863164

28. Huang D, Tan X, Liu T, Chu E, Kong F (2020) Effects of hierarchical city centers on the intensity and direction of urban land expansion: a case study of Beijing. Land 9(9):1-19. https://doi. org/10.3390/land9090312

29. Sunil N, Sivaraj N, Anitha K, Abraham B, Kumar V, Sudhir E, Vanaja $M$, Varaprasad KS (2009) Analysis of diversity and distribution of Jatropha curcas L. germplasm using Geographic Information System (DIVA-GIS). Genet Resour Crop Evol 56:115-119. https:// doi.org/10.1007/s10722-008-9350-x

30. NextGIS (2013) MOLUSCE-quick and convenient analysis of land cover changes. https://nextgis.com/blog/molusce/ Accessed 26 Dec 2019

31. Mazumder S, Datta D (2019) Spatial pattern of urban and periurban aquaculture in Kolkata Metropolitan Area, India. Int J Innov Stud Sociol Humanit 4(1):34-43
32. Dutta V (2012) Land use dynamics and peri-urban growth characteristics: reflections on master plan and urban suitability from a sprawling north Indian city. Environ Urban Asia 3(2):277-301. https://doi.org/10.1177/0975425312473226

33. Gupta R, Gangopadhyay SG (2013) Urban food security through urban agriculture and waste recycling: some lessons for India. Vikalpa 38(3):13-22

Publisher's Note Springer Nature remains neutral with regard to jurisdictional claims in published maps and institutional affiliations. 